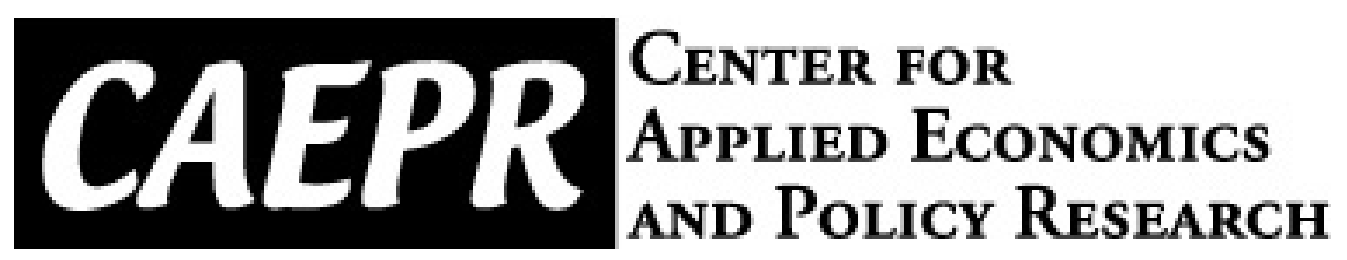

CAEPR Working Paper

\#2008-019

\title{
Socio-Economic Status, HIVIAIDS Knowledge and Stigma, and Sexual Behavior in India
}

\author{
Pedro de Araujo \\ Indiana University Bloomington \\ Original: July 14, 2008 \\ Updated: September 11, 2008
}

This paper can be downloaded without charge from the Social Science Research Network electronic library at: http://ssrn.com/abstract=1159889.

The Center for Applied Economics and Policy Research resides in the Department of Economics at Indiana University Bloomington. CAEPR can be found on the Internet at:

http://www.indiana.edu/ caepr. CAEPR can be reached via email at caepr@indiana.edu or via phone at 812-855-4050.

(C2008 by Pedro de Araujo. All rights reserved. Short sections of text, not to exceed two paragraphs, may be quoted without explicit permission provided that full credit, including ${ }^{\odot}$ notice, is given to the source. 


\title{
Socio-Economic Status, HIV/AIDS Knowledge and Stigma, and Sexual Behavior in India
}

\author{
Pedro Falcão de Araujo* \\ Colorado College
}

Revised Version: August 25, 2008

\begin{abstract}
Using data from the National Family Health Surveys (NFHS-3), this paper analyzes the socioeconomic correlates of sexual behavior, HIV/AIDS knowledge and stigma in India. The main findings are that, overall, the Indian population is faithful and abstains from sex with very small variations across socioeconomic classes. However, given the large size of the population, there is still room for some concern as condom use is low, knowledge about the disease is poor, and stigma is high; specially with respect to less educated, poorer, single males and women in general. Obvious policy recommendations are; therefore, to increase condom distribution and awareness, increase very heavily HIV/AIDS basic education, and promote women empowerment with respect to sexual choices.
\end{abstract}

Key Words: HIV/AIDS, Condom, Stigma, and India

JEL Classification: C13, C25, and O53

\footnotetext{
${ }^{*}$ I would like to thank Gerhard Glomm, Rusty Tchernis, Kim Huynh, and Brian Peterson for very helpful comments and suggestions. All errors are my own.

${ }^{\dagger}$ Contact Information: Pedro.deAraujo@coloradocollege.edu
} 


\section{Introduction}

In the most recent AIDS epidemic update regional summary in Asia (UNAIDS (2007b)), it has been estimated that 2.5 million people in India have HIV and that adult national HIV prevalence is $0.36 \%$. In some states, HIV prevalence is as high as $1.13 \%$. Even though prevalence in India is much lower when compared to some sub-Saharan African countries, the absolute number of infections can be much higher. The fact that India has a population of 1.13 billion people makes HIV/AIDS in this country a point of much concern.

This paper investigates the socioeconomic correlates measured by education, wealth, marital status, and place of residence; of knowledge about AIDS, sexual behavior, and AIDS related stigma in India using population based data from the last available National Family Health Surveys (NFHS-3). Since this data is representative of the entire Indian population, the results are more general and less susceptible to location and selection biases.

One of the most important aspects of this study is the ability it has to identify segments of the general population that are more susceptible to acquiring HIV. Therefore, it becomes clearer where preventive policies should be targeted.

Previous studies investigating the relationship between HIV/AIDS and sexual behavior, HIV/AIDS knowledge and stigma in India have not used representative population samples. Bharat, Aggleton, and Tyrer (2001) using data from Mumbai and Bombay conclude that HIV/AIDS denial and stigma are very high in India reaching hospitals, the place of employment, schools, and even families. Ambati, Ambati, and Rao (1997) using data from educated individuals in southern India conclude that this subgroup of the population have very good knowledge about the disease and support policies to increase AIDS awareness in the population; however, stigma was still found to be somewhat high. The current study shows that knowledge about AIDS in the population is actually very low, but increases with education and wealth. Stigma is also found to be high, but decreasing in education and wealth.

Godbole and Mehendale (2005) report that the main concerns about HIV/AIDS in India are the increase in the number of infected women, stigma, and discrimination; some of their preventive policies suggestions include an increase in condom distribution, 
increases in AIDS education among young people and women, and improvements in women's status; this paper recommends similar policies.

Sexual behavior has not been widely investigated in India. Understanding how people behave when faced with sexual choices is key in enlightening policy makers on how to design successful preventive policies. The so called ABC model of HIV

prevention, which has been widely used in the developing world, focuses on three pillars: abstinence, faithfulness, and condom use. The data suggests that the Indian population has high levels of abstinence and faithfulness, and this paper finds a positive association between these behaviors and socioeconomic status. However, condom is not widely used, even in the never married population, specially for women and young single males.

The remainder of this paper is organized as follows. Section 2 describes the data with relevant descriptive statistics. Section 3 discusses all the estimation results and section 4 concludes.

\section{Data and Descriptive Statistics}

The data in this paper is part of the third wave of the National Family Health Surveys (NFHS-3) in India. This is a population based survey with the goal to provide information about the studied population on family planning, health, nutrition, disease, and more recently HIV/AIDS. In the survey, there are different units of observation. Data was collected on males, females, children, and households. Since the objective of this paper is to investigate the socioeconomic correlates of sexual behavior, and HIV knowledge and stigma at the individual level; variables were selected as to capture these effects only using males and females responses.

There are 8 dependent variables in the analysis; five of them measure individual sexual behavior, two measure HIV/AIDS knowledge, and one variable captures HIV/AIDS stigma. Most of these variables are also used in de Walque (2006) and Corno and de Walque (2007), which makes the results comparable with studies from other countries. Out of the five variables measuring sexual behavior, three disclose information on abstinence, while the remainder two disclose information on condom use and fidelity. It is important to notice that these sexual behavior variables encompasses the three 
pillars of HIV/AIDS preventive education advocated by donor countries, especially the United States (PEPFAR), and international agencies in the form of ABC campaigns. Below is a description of these variables ${ }^{1}$ :

\section{Dependent Variables:}

- CU: condom use - interviewees were asked if they used a condom in last sexual intercourse.

- EMS: fidelity - number of sexual partners excluding husband or wife within last year (married individuals only).

- ABT: abstinence - time in months of last sexual encounter (excludes virgins).

- VIR: abstinence - interviewees were asked if they have ever had sex (only never married individuals).

- FS: abstinence - age in years of first sexual intercourse (excludes virgins).

- EHA: HIV/AIDS knowledge - interviewees were asked if they ever heard of AIDS.

- HLP: HIV/AIDS knowledge - interviewees were asked if a healthy looking person can have AIDS.

- VEG: HIV/AIDS stigma - interviewees were asked if they would buy vegetables from an AIDS infected person.

Table 1 reports the weighted means and standard errors for these variables. With the exception of VEG, there are significant differences in the means between males and females. Some of the values reported in table 1 are alarming. While $83 \%$ of males report they have heard of AIDS, only $61 \%$ of females do so. This implies that the absolute number of people that never heard about AIDS is very large in India, with the majority being females. This could be do to the fact that males are on average more educated than females (see table 2).

The other variable that captures knowledge about the disease (HLP) indicates that $27 \%$ of males and $38 \%$ of females do not know that a healthy looking person can have AIDS. These two variables suggest very poor knowledge about the disease in the population. Even though stigma about AIDS seems not to vary across gender, it is very

\footnotetext{
${ }^{1}$ For a more precise description of all variables use in this paper, see table 11
} 
strong, as $36 \%$ of males and $37 \%$ of females report that they would not buy vegetables from an HIV infected person.

With respect to sexual behavior, not many people report using condoms in last sexual intercourse; $8.7 \%$ of males and $6.9 \%$ of females, or being unfaithful; $1.4 \%$ of males and $0.01 \%$ of females. Also, there is a large number of virgins in the never married population in India; $86.4 \%$ of males and $99.2 \%$ of females. One surprising statistic is the average age of first sexual intercourse in males. Males report an average age of 21 years, which is not only higher compared to females (19 years), but much higher than males in Lesotho for example (Corno and de Walque (2007)).

These numbers suggest that overall, the Indian population is abstaining from sex and being faithful ${ }^{2}$, which are two important steps in preventing the spread of HIV. It seems though that this behavior is not necessarily because AIDS is perceived as a problem, given that AIDS knowledge is limited, but more because of cultural and social characteristics in that region.

The responses about condom use indicate that a very low percentage of individuals are in fact using it. Even when means are calculated for only non-married and sexually active individuals, the proportion of people that claim that a condom was used in last intercourse is still low, although much higher in males ${ }^{3}$. This suggests that condom distribution programs coupled with HIV/AIDS education could potentially be the successful route in combating the spread of the disease.

The next step is then to investigate if there are any significant differences in these responses across socioeconomic spheres, which will be left for the following section. To do this, one needs to define the list of independent variables used in the analysis. These variables measure not only socioeconomic characteristics of the population, but also age, place of residence, and religion. Below is a description of these variables.

\section{Independent Variables:}

- AGE: age groups in years - the following age groups were recorded: 15-19, 20-24, 25-29, 30-34, 35-39, 40-44, 45-49, 50-54 .

- EDUC: level of education - this variable was divided into four categories: no

\footnotetext{
${ }^{2}$ Even if people over report faithfulness, the numbers are still extraordinary.

${ }^{3} 39 \%$ for males and $6.9 \%$ for females.

${ }^{4}$ only males.
} 
education, primary education, secondary education, and higher education; which corresponds to the following number of years of education respectively: less than one year, between one and five years, between six and twelve years, and more than twelve years.

- WEALTH: wealth index - constructed using household assets; five categories divided in quintiles ${ }^{5}$.

- MS: marital status - this variable has three categories: never married $^{6}$, currently married, and formerly married.

- LOC: location - this variable has two categories: urban or rural.

- REL: religion - the following categories were recorded: Hindu, Muslim, Christian, Sikh, Buddhist/neo-Buddhist, Jain, Jewish, Parsi/Zoroastrian, Donyi Polo, no religion, and other.

- STATE: state - the following states and territories were recorded: Jammu and Kashmir, Himachal Pradesh, Punjab, Uttaranchal, Haryana, Delhi, Rajasthan, Uttar Pradesh, Bihar, Sikkim, Arunachal Pradesh, Nagaland, Manipur, Mizoram, Tripura, Meghalaya, Assam, West Bengal, Jharkhand, Orissa, Chhattisgarh, Madhya Pradesh, Gujarat, Maharashtra, Andhra Pradesh, Karnataka, Goa, Kerala, and Tamil Nadu.

The analysis mainly focuses on the effects of education, wealth, location, marital status, and age on sexual behavior, AIDS knowledge, and stigma. The variables religion and state are used as controls. Table 2 has descriptive statistics for most independent variables. Wealth is omitted from the table since it's distribution is uniform conditional on quintiles, that is, the proportion of each category is 0.2 by design.

It is very noticeable that the age distribution is very similar across gender; $48 \%$ of males and $54 \%$ of females report having less than 30 years of age. The fact that an estimated half of the population falls within these boundaries, and since this is the age group more susceptible to acquiring HIV, special attention should be given to this segment of the population.

\footnotetext{
${ }^{5}$ For a precise description of this index see the supplemental documentation in NFHS-3.

${ }^{6}$ Includes respondents with Gauna not performed
} 
Even though the proportion of individuals with no education is very large; $18.5 \%$ for males and $40.5 \%$ for females, on average, males are more educated than females. While $55 \%$ of females report having less than a secondary education, $64 \%$ of males report having at least secondary education. Both of these indicators can potentially pose a challenge in the design of educational campaigns that teach about HIV/AIDS. About one third of males and females live in urban areas with the remaining living in rural areas. This is consistent with other poor developing countries.

More females than males are currently married with a proportion equal to $75 \%$ for females and $64 \%$ for males. This implies a greater proportion of single males in the country. A point of concern is that combining some of the statistics presented so far, the supposition that sexually active young single males with limited knowledge about HIV/AIDS are engaging in unprotected sex can be made, which can be dangerous for the spread of the disease. The following section presents a set of results from regression analysis with the variables described above.

\section{Results}

Tables 3 to 10 display the results. The first five tables investigate the socioeconomic correlates of sexual behavior, while the remaining three assess HIV/AIDS knowledge and stigma. Since most AIDS prevention programs have the objective to promote abstinence, faithfulness, and condom use (ABC campaigns); each regression estimating sexual behavior has one of the three objectives as the dependent variable. Out of the remaining three regressions, two focuses on AIDS knowledge and one on stigma.

With the exception of FS, all other dependent variables are discrete and binary. Hence, a probit regression was fit in each of these cases and ordinary least squares was used in the remaining variable. The benchmark case in each regression is a 15 to 19 year old never married individual with no education, in the poorest wealth quintile, and living in a rural area.

Since all the regressors are categorical, calculating the effects of a change in one of the independent variables on the probability of the dependent variable is more complicated in the probit regressions. Just using the difference in probabilities when one regressor changes evaluated at the mean of every other independent variable has very 
little meaning because the average does not represent an actual observation. Hence, average partial effects (APE) were calculated using the method found in Chamberlain (1982), which consists of evaluating the average of all partial effects calculated for each observation $^{7}$. The delta method can then be used to compute robust standard errors of these average partial effects. In what follows, each regression model is analyzed in detail.

\subsection{Sexual Behavior}

\subsubsection{Condom Use}

The use of a condom is recommended in every sexual act as a way to decrease the probability of becoming HIV infected. This is true even for married couples. Table 3 presents results from a probit model where respondents were asked if they used a condom during their last sexual intercourse. Three regressions are estimated; one for all males, one for only never married males, and one for all females. Since almost all married respondents report never having extra-marital sex, it was not possible to separate sex with spouse, from sex with someone other than spouse as de Walque (2006) and Corno and de Walque (2007) do. This is why separate regression for only never married males is estimated.

The results indicate that the likelihood of condom use is increasing in education and wealth for all males. That is, a male with higher education is $10.45 \%$ more likely to use a condom than a male with no education. Also, the richest of males is $10.15 \%$ more likely to use a condom than the poorest of males. The reported APE indicates that the wealthier and more educated a males is, the larger the likelihood of condom use in sex. Living in an urban location slightly increases the likelihood of condom use. Currently married males are $24 \%$ less likely to use condoms for sex, which might not be such a problem since married couples appear to be very faithful in India.

When the model was fit only using never married males, only the two top wealth quintiles and location presented significant coefficients. However, the APE on these coefficients is much larger. The wealthiest $20 \%$ of never married males are $32.96 \%$

\footnotetext{
${ }^{7}$ In order to implement this calculation in Stata; see http://glue.umd.edu/gelbach/ado/margfx.ado for the code, and http://glue.umd.edu/gelbach/ado/margfx.pdf for a description on how to use the command.
} 
more likely to use a condom than the poorest; while the second wealthiest quintile of never married males is $21.73 \%$ more likely to use condoms when compared to the same group. This information can potentially be important in preventive campaigns since only $40 \%$ of never married males report having used condoms in last sexual intercourse, which implies a very low use of condoms for single men in India, specially in the bottom of the wealth distribution.

Socioeconomic status is not an important determinant of condom use for females. This result differs with respect to findings in Corno and de Walque (2007) for the country of Lesotho. There are two hypothetical explanations for these findings. First, it is possible that the decision to use condoms pertains mostly to males in India, and second, it is possible that sexual encounters across never married individuals is uncorrelated with wealth and education of women. That is, never married males do not use socioeconomic status in their decision to have sex with females and since they are the ones making the decision about condoms, it is expected that socioeconomic status is not a good predictor in the female equation; specially when married couples report a very low incidence of condom use.

\subsubsection{Faithfulness}

Another pillar of preventive HIV/AIDS campaigns is faithfulness. If a married couple is faithful to one another throughout their marriage, the probability of either one acquiring HIV is very low; assuming the couple does not use injectable drugs. Even though the great majority of married respondents in the survey claim to be faithful, table 4 estimates the socioeconomic effects of extra marital sex. The results indicate that wealth and education have no effect in the decision to engage in extra marital sex in India. While males living in urban areas are less likely to engage in extra marital sex, females are more likely. However, the magnitude of the APE in both regressions is very insignificant; $-0.4 \%$ for males, and $0.1 \%$ for females.

Younger married males are less likely to be faithful than older males. The probability of engaging in extra marital sex for males over the age of 25 is about $1.1 \%$ lower when compared to younger males. Again, the magnitude of this effect, even though significant, is very small. 


\subsubsection{Abstinence}

Abstinence is the last pillar in HIV/AIDS preventive campaigns. It is quite obvious that the least amount of sex someone has or the later it takes for someone to begin their sexual life reduces the probability of contracting HIV. Three variables are used to assess the effects of socioeconomic status on abstinence: the time since last sexual intercourse, if ever had sex, and the age at first sex. The first variable captures possible reductions in sexual activity, while the remaining two captures the time of sexual debut.

\section{Time Since Last Sex}

Table 5 has the results relating socioeconomic status to abstinence measured by the time since last sexual intercourse. The dependent variable, therefore, equals one if the individual's last sexual intercourse occurred in more than one year, and zero otherwise. In this regression, virgins were not included. All wealth variables have negative increasing coefficients indicating that the wealthier the individual, the smaller the probability that sex occurred over a year. That is, wealthier individuals abstain less. However, the APE of this wealth effect, even though higher for women, is in general small. Only the educational level for males has a significant association with the dependent variable; following the same results as wealth, the more educated males tend to abstain less, but again, the APEs are quite small.

In general, the results indicate that older males are more likely to abstain from sex. The APE relative to ages 15 to 19 of the age groups 40 to 44,45 to 50 , and 51 to 54 is $12.06 \%, 17.19 \%$, and $26.77 \%$ respectively. Abstinence in females is non-linear with respect to age. Females in the age groups 25 to 29 through 40 to 44 abstain less relative to females between the ages of 15 to 19 . The greatest average partial difference occurs between females between the ages 35 to 39 and 45 to 49 , where the likelihood difference in abstinence is $7 \%$. That is, the older age group is $7 \%$ more likely to abstain from sex than females between the ages of 35 and 39 .

Currently married individuals are much less likely to abstain, with APE of $48.96 \%$ for males and $14.69 \%$ for females relative to never married individuals. Living in an urban location reduces the probability of abstinence in both male and female regressions, however, the APE are very small.

Virginity 
Never married individuals were asked if they had had sexual intercourse yet. This variable was then used to assess the association between virginity and socioeconomic status and results are displayed in table 6 . The main findings are that wealth and education tends to delay first sexual encounter for both males and females. Even though there is no statistical significance in the coefficients representing secondary education and the poorer wealth quintile, which indicates that there is no difference in the likelihood of being a virgin between the poorest and most uneducated people and that particular group; all the coefficients on higher education and the middle wealth quintile and above are statistically significant and positive.

However, the APE are quite different in the males and females regression. While there is a $5.84 \%$ increase in the probability of being a virgin in the richest quintile for males, this probability is only $0.9 \%$ for females. These numbers follow the same pattern as we move to the richer and middle quintiles, which suggests that the results for males are more robust than the results for females. The same pattern in the partial effects occurs with higher education, while it is $4.1 \%$ for males, it is only $0.5 \%$ for females.

It is not surprising that age is negatively correlated with virginity. The results, therefore, indicate that the older the individual, the less likely it is that he or she is a virgin. Again the APE are much larger for males, which could indicate that older never married males are more sexually active than older never married females. Location has no effect on virginity of males and females, the likelihood of being a virgin is the same for individuals living in rural and urban areas.

\section{Age at First Sex}

The last variable measuring abstinence is the age of first sexual intercourse. Table 7 has the results from ordinary least squares regression with age of sexual debut as the dependent variable for non virgins only. In the regression for males; education, wealth, marital status, age, and location are statistically significant and positive. The results indicate that males with higher education take on average 3 more years to initiate their sexual life. Also, the wealthiest quintile waits 1.6 years more to have sex compared to the poorest quintile.

Younger individuals report a much younger age for sexual initiation. Males aged thirty and above start their sexual life an average of 5 years later than males between the ages of 15 and 19. This could potentially be happening because only males with 
sexual experience were included, and therefore, all males between the ages 15 and 19 must have had a sexual encounter with an average age of no more than 19.

The results for females are very similar to males with respect to education and age, however, wealth seems to play almost no role in the age females decide to have sex. A very large difference in effects between males and females happens with respect to marital status. While currently married females on average start sex 6 years younger than never married females, currently married males start sex 1 year older. This result suggests that females marry at a younger age than males. Another result from this model is that males and females living in urban areas abstain from sex on average 6 to 8 months more compared to males and females in rural areas.

After analyzing all the socioeconomic correlates of sexual behavior, some interesting conclusions can be made. In general, fidelity and abstinence are high in India and vary little across socioeconomic classes. The marginal effects reported in the majority of regressions dealing with these two issues are small, which suggests that even where statistically significant differences in wealth and education are found, the magnitude of these differences are negligible. This implies that overall, the Indian population is well suited in these two respects to face a possible HIV/AIDS epidemic.

A realistic point of concern, is the fact that condom is not widely used in India and less educated and poorer males are much less likely to use them. Also, this same demographic has a higher probability of being sexually active and waiting less years before sexual debut, which puts them at a higher risk of contamination. In addition, the fact that no socioeconomic correlate, not even marital status, is associated with condom use for females suggests that female empowerment in sexual decisions might be needed in order to reduce the risk of spread in females.

\section{$3.2 \mathrm{HIV} / \mathrm{AIDS}$ Knowledge}

Two variables in the analysis capture HIV/AIDS knowledge in the Indian population. The first, measures general knowledge of the disease's existence. Individuals were asked if they ever heard of AIDS. The second, measures more specific knowledge about the disease. Out of everyone that ever heard about AIDS, individuals were asked if a healthy looking person could have AIDS. In general, as reported before, knowledge about AIDS 
is very poor in India. Only $83 \%$ of males and $61 \%$ of females report they have heard of AIDS; and only $74 \%$ of males and $62 \%$ of females report that a healthy looking person can have AIDS (table 1). Below are the findings from two regressions of these two variables.

\section{Ever Heard of AIDS}

In table 8 almost every variable in both regressions is statistically significant with somewhat large APE. General knowledge about the existence of AIDS is increasing in wealth, with the wealthiest males being $14.35 \%$ more likely to have heard of AIDS than the poorest males. In the female regression this same APE equals $28.39 \%$. Males and females in the fourth wealth quintile are $12.18 \%$ and $21.30 \%$ more likely to have heard of AIDS than males and females in the lowest wealth quintile respectively. For males and females in quintiles three and two, the APE is $9.26 \%$ and $5.75 \%$ for males and $13.54 \%$ and $7.11 \%$ for females.

One surprising result is that males with higher education, even though more likely to have heard of AIDS than males with no education, are $4.2 \%$ less likely to have heard of AIDS when compared with males with only secondary education. However, it is still reasonable to conclude that more educated individuals have a better chance to know about the existence of AIDS than do individuals with no education.

Currently married women are $1.9 \%$ less likely to know about AIDS than never married women. This same result is not true for males, where there is no statistical difference in knowledge about AIDS between never married and currently married males. Both regressions also show that location plays some role in knowledge, that is, males and females living in urban locations are $5 \%$ and $6.45 \%$ more likely to have heard of AIDS than males and females in rural areas.

There is some evidence that the effect of age on knowledge is non linear. Males and females between the ages of 20 and 40 appear to have more knowledge about AIDS than young males and females; the opposite is the case for males and females 40 years old or older.

\section{Can Healthy Looking Person Have AIDS}

Conditioning on knowledge about the existence of AIDS, the results displayed in table 9 are not surprising. Even though all individuals in that sample knows about AIDS, more educated and wealthier people are more likely to know more about the 
disease. The likelihood of knowing that a healthy looking person can have AIDS is increasing in education and wealth for both males and females.

Males with primary education are $3.07 \%$ more likely to know that a healthy looking person can have AIDS than males with no education. The likelihood of knowing about this is even larger for males with secondary education and higher education compared to males with no education; $12.27 \%$ and $19.66 \%$ respectively. The APE on the female regression of these three educational levels is $2.01 \%, 11.81 \%$, and $25.50 \%$.

Wealth follows the same pattern as education. Compared to the poorest wealth quintile, the APE for males equal 1.65\%, 4.16\%, 8.34\%, and $13.37 \%$ going from poorer to richest. In the female regression these same effects equal $1.26 \%, 4.44 \%, 8.08 \%$, and $13.99 \%$.

Age has very little effect on the female regression with the only statistical significant difference occurring in females between the age 45 and 49 , where they are $2.31 \%$ less likely to know that a healthy looking person can have AIDS. In the male regression, age has a positive but non linear effect. Every age group is more likely to know the answer to the question than males between the age 15 and 19, however, males aged 25 to 29 have more knowledge compared to older males.

While marital status has no effect on this measurement of knowledge, location has a positive and significant effect. Males and females living in an urban areas are $1.7 \%$ and $1.38 \%$ more likely to know that a healthy looking person can have AIDS compared to males and females from rural areas respectively.

\subsection{HIV/AIDS Stigma}

HIV/AIDS stigma is being measured in this paper by asking individuals if they would by vegetables from an HIV infected person. Again, the sample only includes individuals that indicated knowledge of the existence of AIDS. The results are displayed in table 10, and the effects reported for males and females are very much alike.

The more educated the individual, the less stigma it has. Compared with not educated males, males with higher education are $27.18 \%$ less likely not to buy vegetables from someone HIV infected. These effects are equal to $14.28 \%$ and $2.94 \%$ for males with secondary and primary education respectively. These effects in the female regression 
are equal to $27.14 \%, 14.54 \%$, and $3.63 \%$ going from higher to primary education.

Wealth follows the same pattern as education with increasing partial effects. There is a decreasing relationship between stigma and wealth, with decreasing APE. Going from the richest quintile to the poorer, compared to the poorest quintile, males are $19.56 \%$, $14.89 \%, 8.25 \%$, and $4.38 \%$ less likely not to buy vegetables from an HIV infected person respectively. The numbers for females are smaller than for males but follows the same direction.

More stigma can be associated with marital status; both married males and females are more likely not to buy vegetables from someone with AIDS. The marginal effects are $4.52 \%$ for males and $4.41 \%$ for females. Also, it seems that older individuals have more stigma; the regression coefficients on people older than 40 are positive and statistically significant in both regressions.

Lastly, living in an urban area is negatively associated with stigma. Urban males are $5.04 \%$ less likely not to buy vegetables from an infected person and urban females are $3.08 \%$ less likely as well.

\section{Conclusion}

The overall perception that one has after this analysis is that much has to be done to improve basic information about HIV/AIDS in India. Specially for less educated and poorer individuals. For ABC campaigns to be successful, first it is necessary that the population knows exactly what HIV/AIDS is, and it is apparent that this is not the case in India.

Also, according to the data, the Indian population is very well behaved with respect to faithfulness and absenteeism, but not so much with respect to condom use. It is the combination of poor HIV/AIDS knowledge and low condom use that makes a great segment of the Indian population vulnerable to HIV infection. This vulnerability is mostly on young, uneducated, and poor single males as well as most single women.

The obvious policy recommendation is, therefore, not to focus so much on the first two pillars of the $\mathrm{ABC}$ tripod, but to mostly focus resources on condom distribution programs, HIV/AIDS education, and women empowerment. Specially on the less privileged segment of the population. 


\section{References}

Ambati, B. K., J. Ambati, And A. M. Rao (1997): "Dynamics of Knowledge and Attitudes about AIDS among the Educated in Southern India," AIDS Care, 9(3), 319-330.

Bharat, S., P. Aggleton, And P. Tyrer (2001): "India: HIV and AIDS-related Discrimination, Stigmatization and Denial," UNAIDS Best Practice Collection.

Chamberlain, G. (1982): "Multivariate Regression Models for Panel Data," Journal of Econometrics, 18(1), 5-46.

Corno, L., And D. DE Walque (2007): "The Determinants of HIV Infection and Related Sexual Behaviors: Evidence from Lesotho," Policy Research Working Paper 4421.

DE Walque, D. (2006): "Who Gets AIDS and How? The Determinants of HIV Infection and Sexual Behaviors in Burkina Faso, Cameroon, Ghana, Kenya, and Tanzania," World Bank Policy Research Working Paper 3844.

- (2007): "How does the impact of an HIV/AIDS information campaign vary with educational attainment? Evidence from rural Uganda," Journal of Development Economics, 84, 686-714.

Dinkelman, T., J. Levinsohn, and R. Majelantle (2006): "When Knowledge is not Enough: HIV/AIDS Information and Risky Behavior in Botswana," Research Seminar in International Economics Discussion Paper No. 553.

Fylkesnes, K., ET AL. (1997): "The HIV Epidemic in Zambia: Socio-Demographic Prevalence patterns and Indicators of Trends Among Childbearing Women," AIDS, $11,339-345$.

- (2001): "Declining HIV Prevalence and Risk Behaviours in Zambia: Evidence from Surveillance and Population-Based Surveys," AIDS, 15, 907-916.

Gersovitz, M. (2005): "The HIV Epidemic in Four African Countries Seen Through the Demographic and Health Surveys," Journal of African Economies, 14(2), 191-246.

Godbole, S., And S. Mehendale (2005): "HIV/AIDS epidemic in India: risk factors, risk behaviour \& strategies for prevention \& control," Indian Journal of Medical Research, 121, 356-368.

Hargreaves, J., ET AL. (2002): "Socioeconomic Status and Risk of HIV Infection in an Urban Population in Kenya," Tropical Medicine and International Health, 7(9), 793-802.

Hargreaves, J., And J. Glynn (2002): "Educational Attainment and HIV-I Infection in Developing Countries: a Systematic Review," Tropical Medicine and International Health, 7(6), 489-498.

Kilian, A., ET AL. (1999): "Reductions in Risk Behaviour Provide the Most Consistent Explanation for Declining HIV-1 Prevalence in Uganda," AIDS, 13, 391-398.

Le R. Booysen, F., And J. Summerton (2002): "Poverty, Risky Behaviour, and Vulnerability to HIV Infection: Evidence from South Africa," Journal of Health, Population, and Nutrition, pp. 1-4.

Piot, P., And M. Over (1993): HIV Infection and Sexually Transmitted Diseases in Disease Control Priorities in Developing Countries. Oxford University Press.

Quigley, M., ET AL. (1997): "Sexual behaviour patterns and other risk factors for HIV infection in rural Tanzania: a case-control study," AIDS, 11, 237-248. 
UNAIDS (2007a): “AIDS Epidemic Update," Special Report on HIV/AIDS.

_ (2007b): "AIDS Epidemic Update Asia: Regional Summary," Special Report on HIV/AIDS.

Vandermoortele, J., And E. Delamonica (2000): "The "Education Vaccine" Against HIV," Current Issues in Comparative Education, 3(1).

WoJcicki, J. M. (2005): "Socioeconomic Status as a Risk Factor for HIV Infection in Women in East, Central, and Southern Africa: A Systematic Review," Journal of Biosocial Science, 37, 1-36.

Wooldridge, J. M. (2002): Econometric Analysis of Cross Section and Panel Data. MIT Press.

World Food Programme (2006): "Literature Review on the Impact of Education Levels on HIV/AIDS Prevalence Rates," WFP, pp. 1-15. 


\section{A Tables}

Table 1: Descriptive Statistics of Dependent Variables

\begin{tabular}{|c|c|c|c|c|c|c|}
\hline \multirow[t]{2}{*}{ Dependent Variables } & \multicolumn{3}{|c|}{ Males } & \multicolumn{3}{|c|}{ Females } \\
\hline & Mean & SE & Obs. & Mean & SE & Obs. \\
\hline $\mathrm{CU}(=1$ if used condom in last sex $)$ & 0.087 & 0.001 & 45328 & 0.069 & 0.001 & 84271 \\
\hline $\operatorname{EMS}(=1$ if $\#$ of sex $\neq$ wif $/$ husb $>0$ in past year $)$ & 0.014 & 0.0008 & 44884 & 0.0018 & 0.0001 & 87951 \\
\hline $\mathrm{ABT}(=1$ if last sex $>$ year - excludes virgins $)$ & 0.050 & 0.001 & 49610 & 0.114 & 0.001 & 93994 \\
\hline $\operatorname{VIR}(=1$ if virgin - never married only $)$ & 0.864 & 0.003 & 28486 & 0.992 & 0.0006 & 30661 \\
\hline $\mathrm{FS}(=$ age in years of first sex - excludes virgins $)$ & 21.62 & 0.028 & 49728 & 19.41 & 0.057 & 93993 \\
\hline $\mathrm{EHA}(=1$ if ever heard of AIDS $)$ & 0.829 & 0.002 & 74362 & 0.609 & 0.001 & 124385 \\
\hline $\operatorname{HLP}(=1$ knows healthy looking person can have AIDS $)$ & 0.732 & 0.002 & 65993 & 0.617 & 0.002 & 88382 \\
\hline $\operatorname{VEG}(=1$ do not buy veg. from person with AIDS $)$ & 0.361 & 0.002 & 63745 & 0.369 & 0.002 & 83836 \\
\hline
\end{tabular}

Note: all variables weighted with recommended sample weights. 
Table 2: Descriptive Statistics of Independent Variables

\begin{tabular}{lcccccc}
\hline \hline Independent Variables & \multicolumn{3}{c}{ Males } & \multicolumn{3}{c}{ Females } \\
& Mean & SE & Obs. & Mean & SE & Obs. \\
\hline AGE1 (15-19) & 0.174 & 0.0019 & 74369 & 0.199 & 0.0014 & 124385 \\
AGE2 (20-24) & 0.161 & 0.0018 & 74369 & 0.183 & 0.0014 & 124385 \\
AGE3 (25-29) & 0.145 & 0.0017 & 74369 & 0.164 & 0.0013 & 124385 \\
AGE4 (30-34) & 0.131 & 0.0017 & 74369 & 0.141 & 0.0012 & 124385 \\
AGE5 (35-39) & 0.125 & 0.0016 & 74369 & 0.127 & 0.0012 & 124385 \\
AGE6 (40-44) & 0.108 & 0.0016 & 74369 & 0.104 & 0.0011 & 124385 \\
AGE7 (45-49) & 0.090 & 0.0014 & 74369 & 0.078 & 0.0010 & 124385 \\
AGE8 (50-54) & 0.062 & 0.0012 & 74369 & n.a. & n.a. & n.a. \\
EDUC1 (no education) & 0.185 & 0.0020 & 74338 & 0.405 & 0.0018 & 124385 \\
EDUC2 (primary education) & 0.170 & 0.001 & 74338 & 0.147 & 0.0013 & 124385 \\
EDUC3 (secondary education) & 0.520 & 0.0025 & 74338 & 0.374 & 0.0017 & 124385 \\
EDUC4 (higher education) & 0.124 & 0.0016 & 74338 & 0.072 & 0.0008 & 124385 \\
MS1 (never married) & 0.341 & 0.0023 & 74369 & 0.204 & 0.0014 & 124385 \\
MS2 (currently married) & 0.643 & 0.0024 & 74369 & 0.748 & 0.0015 & 124385 \\
MS3 (formerly married) & 0.014 & 0.0006 & 74369 & 0.046 & 0.0007 & 124385 \\
LOC (urban) & 0.365 & 0.0023 & 74369 & 0.328 & 0.0016 & 124385 \\
\hline \hline
\end{tabular}

Note: all variables weighted with recommended sample weights. 
Table 3: Condom Use

\begin{tabular}{|c|c|c|c|c|c|c|}
\hline \multicolumn{7}{|c|}{ Dependent Variable $=1$ if used condom in last sexual intercourse } \\
\hline \multirow[t]{2}{*}{ Independent Variables } & \multicolumn{2}{|c|}{ All Males } & \multicolumn{2}{|c|}{ Never Married Males } & \multicolumn{2}{|c|}{ Females } \\
\hline & Coeff. & APE & Coeff. & APE & Coeff. & APE \\
\hline \multirow[t]{2}{*}{ EDUC2 (Primary Education) } & 0.0793 & 0.0107 & -0.2478 & -0.0783 & -0.0133 & -0.0017 \\
\hline & {$[0.0507]$} & {$[0.0052]$} & {$[0.1885]$} & {$[0.0418]$} & {$[0.0278]$} & {$[0.0027]$} \\
\hline \multirow[t]{2}{*}{ EDUC3 (Secondary Education) } & $0.3569 * * *$ & 0.0467 & 0.1419 & 0.0456 & -0.0010 & -0.0001 \\
\hline & {$[0.0422]$} & {$[0.0042]$} & {$[0.1565]$} & {$[0.0356]$} & {$[0.0253]$} & {$[0.0025]$} \\
\hline \multirow[t]{2}{*}{ EDUC4 (Higher Education) } & $0.6217^{* * *}$ & 0.1045 & -0.0456 & -0.0146 & -0.0002 & -0.00002 \\
\hline & {$[0.0512]$} & {$[0.0081]$} & {$[0.2021]$} & {$[0.0461]$} & [0.0393] & {$[0.0042]$} \\
\hline \multirow[t]{2}{*}{ WEALTH2 (Poorer Quintile) } & $0.1442^{* *}$ & 0.0200 & 0.2775 & 0.0889 & -0.0392 & -0.0048 \\
\hline & {$[0.0574]$} & {$[0.0059]$} & {$[0.1741]$} & {$[0.0377]$} & {$[0.0312]$} & {$[0.0028]$} \\
\hline \multirow[t]{2}{*}{ WEALTH3 (Middle Quintile) } & $0.3044^{* * *}$ & 0.0444 & 0.2633 & 0.0845 & -0.0203 & -0.0025 \\
\hline & {$[0.0557]$} & {$[0.0064]$} & {$[0.1768]$} & {$[0.0385]$} & {$[0.0316]$} & {$[0.0029]$} \\
\hline \multirow[t]{2}{*}{ WEALTH4 (Richer Quintile) } & $0.4651^{* * *}$ & 0.0704 & $0.6669 * * *$ & 0.2173 & 0.0285 & 0.0036 \\
\hline & {$[0.0563]$} & {$[0.0070]$} & {$[0.1818]$} & {$[0.0389]$} & {$[0.0337]$} & {$[0.0033]$} \\
\hline \multirow[t]{2}{*}{ WEALTH5 (Richest Quintile) } & $0.6423^{* * *}$ & 0.1015 & $0.9530 * * *$ & 0.3296 & 0.0178 & 0.0022 \\
\hline & {$[0.0598]$} & {$[0.0083]$} & {$[0.2025]$} & {$[0.0452]$} & {$[0.0381]$} & {$[0.0038]$} \\
\hline \multirow[t]{2}{*}{ MS2 (Currently Married) } & $-1.1038^{* * *}$ & -0.2402 & - & - & 0.0084 & 0.0010 \\
\hline & {$[0.0566]$} & {$[0.0125]$} & & & {$[0.0307]$} & {$[0.0030]$} \\
\hline \multirow[t]{2}{*}{ MS3 (Formerly Married) } & $-0.9764^{* * *}$ & -0.0721 & - & - & 0.0586 & 0.0077 \\
\hline & {$[0.2300]$} & {$[0.0052]$} & & & {$[0.0514]$} & {$[0.0055]$} \\
\hline \multirow[t]{2}{*}{ AGE2 (20-24) } & $0.1486^{*}$ & 0.0208 & 0.1261 & 0.0407 & 0.0133 & 0.0017 \\
\hline & {$[0.0833]$} & {$[0.0091]$} & [0.0999] & {$[0.0237]$} & {$[0.0325]$} & {$[0.0032]$} \\
\hline \multirow[t]{2}{*}{ AGE3 (25-29) } & $0.1880^{* *}$ & 0.0264 & 0.1403 & 0.0458 & 0.0410 & 0.0053 \\
\hline & {$[0.0859]$} & {$[0.0094]$} & {$[0.1247]$} & {$[0.0312]$} & {$[0.0367]$} & {$[0.0037]$} \\
\hline \multirow[t]{2}{*}{ AGE4 (30-34) } & $0.2533^{* * *}$ & 0.0362 & 0.2299 & 0.0755 & 0.0071 & 0.0009 \\
\hline & {$[0.0875]$} & {$[0.0098]$} & {$[0.1962]$} & [0.0493] & {$[0.0391]$} & {$[0.0037]$} \\
\hline \multirow[t]{2}{*}{ AGE5 (35-39) } & $0.1823^{* * *}$ & 0.0254 & -0.2933 & -0.0905 & 0.0296 & 0.0038 \\
\hline & {$[0.0890]$} & {$[0.0095]$} & {$[0.2874]$} & {$[0.0802]$} & {$[0.0396]$} & {$[0.0039]$} \\
\hline \multirow[t]{2}{*}{ AGE6 (40-44) } & -0.0066 & -0.0008 & 0.2121 & 0.0696 & -0.0226 & -0.0028 \\
\hline & {$[0.0906]$} & {$[0.0086]$} & {$[0.5311]$} & {$[0.1364]$} & {$[0.0413]$} & {$[0.0039]$} \\
\hline \multirow[t]{2}{*}{ AGE7 (45-49) } & $-0.2753^{* * *}$ & -0.0318 & -0.5722 & -0.1666 & 0.0208 & 0.0026 \\
\hline & [0.0936] & {$[0.0070]$} & {$[0.6540]$} & [0.1239] & {$[0.0447]$} & {$[0.0044]$} \\
\hline \multirow[t]{2}{*}{ AGE8 (50-54) } & $-0.4372^{* * *}$ & -0.0458 & -0.3595 & -0.1094 & n.a. & n.a \\
\hline & {$[0.1050]$} & {$[0.0062]$} & {$[0.4718]$} & {$[0.2283]$} & & \\
\hline \multirow[t]{2}{*}{ LOC (Urban) } & $0.1626^{* * *}$ & 0.0217 & $0.2439^{* *}$ & 0.0812 & -0.0133 & -0.0017 \\
\hline & {$[0.0290]$} & {$[0.0031]$} & {$[0.1071]$} & {$[0.0266]$} & {$[0.0222]$} & {$[0.0022]$} \\
\hline Religion Dummies & yes & & yes & & yes & \\
\hline State Dummies & yes & & yes & & yes & \\
\hline Observations & 45291 & & 1992 & & 84235 & \\
\hline LR-Chi & $4799.7^{* * *}$ & & $409.95^{* * *}$ & & $1771.95^{* * *}$ & \\
\hline McFadden's pseudo $R^{2}$ & 0.179 & & 0.1535 & & 0.04 & \\
\hline
\end{tabular}

Note: all variables weighted with recommended sample weights. Robust standard errors in brackets.

${ }^{*}$ significant at $10 \% ;{ }^{* *}$ significant at $5 \% ;{ }^{* *}$ significant at $1 \%$. APE $=$ average partial effect. 
Table 4: Extra Marital Sex (married individuals only)

\begin{tabular}{|c|c|c|c|c|}
\hline \multicolumn{5}{|c|}{ Dependent Variable $=1$ if number of sexual relations other than wife/husband $>0$ in past year } \\
\hline \multirow[t]{2}{*}{ Independent Variables } & \multicolumn{2}{|c|}{ Males } & \multicolumn{2}{|c|}{ Females } \\
\hline & Coeff. & APE & Coeff. & APE \\
\hline \multirow[t]{2}{*}{ EDUC2 (Primary Education) } & 0.1106 & 0.0040 & -0.1250 & -0.0006 \\
\hline & {$[0.0731]$} & [0.0018] & [0.0937] & [0.0003] \\
\hline \multirow[t]{2}{*}{ EDUC3 (Secondary Education) } & -0.0575 & -0.0019 & -0.1232 & -0.0006 \\
\hline & {$[0.0652]$} & {$[0.0015]$} & {$[0.0801]$} & {$[0.0003]$} \\
\hline \multirow[t]{2}{*}{ EDUC4 (Higher Education) } & -0.0413 & -0.0013 & -0.1483 & -0.0007 \\
\hline & {$[0.1013]$} & {$[0.0023]$} & {$[0.1426]$} & {$[0.0005]$} \\
\hline \multirow[t]{2}{*}{ WEALTH2 (Poorer Quintile) } & -0.0025 & -0.00008 & 0.0033 & 0.00002 \\
\hline & {$[0.0826]$} & {$[0.0018]$} & {$[0.1142]$} & [0.0004] \\
\hline \multirow[t]{2}{*}{ WEALTH3 (Middle Quintile) } & 0.0357 & 0.0012 & -0.1121 & -0.0006 \\
\hline & {$[0.0792]$} & {$[0.0019]$} & {$[0.1113]$} & [0.0004] \\
\hline \multirow[t]{2}{*}{ WEALTH4 (Richer Quintile) } & 0.0533 & 0.0018 & -0.0592 & -0.0003 \\
\hline & {$[0.0897]$} & {$[0.0022]$} & {$[0.1089]$} & {$[0.0005]$} \\
\hline \multirow[t]{2}{*}{ WEALTH5 (Richest Quintile) } & -0.0126 & -0.0004 & -0.0151 & -0.00008 \\
\hline & {$[0.0955]$} & {$[0.0025]$} & {$[0.1284]$} & {$[0.0006]$} \\
\hline \multirow[t]{2}{*}{ AGE2 (20-24) } & -0.2347 & -0.0069 & 0.0560 & 0.0003 \\
\hline & {$[0.2009]$} & {$[0.0030]$} & {$[0.1673]$} & [0.0008] \\
\hline \multirow[t]{2}{*}{ AGE3 (25-29) } & $-0.4698^{* *}$ & -0.0133 & 0.1516 & 0.0010 \\
\hline & [0.1969] & {$[0.0030]$} & {$[0.1613]$} & {$[0.0009]$} \\
\hline \multirow[t]{2}{*}{ AGE4 (30-34) } & $-0.5932^{* * *}$ & -0.0163 & 0.1691 & 0.0011 \\
\hline & [0.1979] & {$[0.0030]$} & {$[0.1606]$} & [0.0009] \\
\hline \multirow[t]{2}{*}{ AGE5 (35-39) } & $-0.6297 * * *$ & -0.0170 & 0.0355 & 0.0002 \\
\hline & [0.1992] & {$[0.0030]$} & {$[0.1710]$} & {$[0.0008]$} \\
\hline \multirow[t]{2}{*}{ AGE6 (40-44) } & $-0.7675 * * *$ & -0.0183 & 0.1112 & 0.0007 \\
\hline & [0.2049] & {$[0.0026]$} & {$[0.1707]$} & [0.0009] \\
\hline \multirow[t]{2}{*}{ AGE7 (45-49) } & $-0.8809 * * *$ & -0.0185 & 0.0282 & 0.0001 \\
\hline & {$[0.2054]$} & {$[0.0022]$} & 0.1765 & [0.0008] \\
\hline \multirow[t]{2}{*}{ AGE8 (50-54) } & $-0.9045^{* * *}$ & -0.0169 & n.a. & n.a. \\
\hline & {$[0.2054]$} & {$[0.0017]$} & & \\
\hline \multirow[t]{2}{*}{ LOC (Urban) } & $-0.1197^{* *}$ & -0.0039 & $0.1673^{* *}$ & 0.0010 \\
\hline & {$[0.0505]$} & {$[0.0013]$} & {$[0.0746]$} & [0.0004] \\
\hline Religion Dummies & yes & & yes & \\
\hline State Dummies & yes & & yes & \\
\hline Observations & 44848 & & 87641 & \\
\hline LR-Chi & $433.68^{* * *}$ & & $108.20^{* * *}$ & \\
\hline McFadden's pseudo $R^{2}$ & 0.06 & & 0.05 & \\
\hline
\end{tabular}

Note: all variables weighted with recommended sample weights. Robust standard errors in brackets.

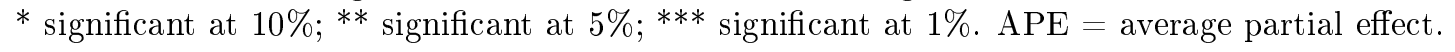


Table 5: Abstinence - time since last sexual intercourse (excludes virgins)

\begin{tabular}{|c|c|c|c|c|}
\hline \multicolumn{5}{|c|}{ Dependent Variable $=1$ if last sexual intercourse $>12$ months } \\
\hline \multirow[t]{2}{*}{ Independent Variables } & \multicolumn{2}{|c|}{ Males } & \multicolumn{2}{|c|}{ Females } \\
\hline & Coeff. & APE & Coeff. & APE \\
\hline \multirow[t]{2}{*}{ EDUC2 (Primary Education) } & -0.0719 & -0.0044 & -0.0308 & -0.0040 \\
\hline & {$[0.053]$} & {$[-0.0022]$} & [0.0243] & [0.0024] \\
\hline \multirow[t]{2}{*}{ EDUC3 (Secondary Education) } & $-0.1194^{* *}$ & -0.0074 & -0.0282 & -0.0037 \\
\hline & {$[0.0500]$} & {$[0.0022]$} & [0.0232] & [0.0023] \\
\hline \multirow[t]{2}{*}{ EDUC4 (Higher Education) } & $-0.1906^{* *}$ & -0.0109 & -0.0483 & -0.0062 \\
\hline & {$[0.0768]$} & {$[0.0030]$} & {$[0.0431]$} & [0.0043] \\
\hline \multirow[t]{2}{*}{ WEALTH2 (Poorer Quintile) } & -0.0563 & -0.0034 & $-0.0778 * * *$ & -0.0100 \\
\hline & {$[0.0608]$} & {$[0.0024]$} & {$[0.0273]$} & [0.0025] \\
\hline \multirow[t]{2}{*}{ WEALTH3 (Middle Quintile) } & $-0.1103^{*}$ & -0.0067 & $-0.1020 * * *$ & -0.0130 \\
\hline & {$[0.0608]$} & {$[0.0024]$} & {$[0.0278]$} & {$[0.0025]$} \\
\hline \multirow[t]{2}{*}{ WEALTH4 (Richer Quintile) } & $-0.1130^{*}$ & -0.0068 & $-0.1443^{* * *}$ & -0.0181 \\
\hline & {$[0.0653]$} & {$[0.0027]$} & {$[0.0308]$} & [0.0028] \\
\hline \multirow[t]{2}{*}{ WEALTH5 (Richest Quintile) } & $-0.2902 * * *$ & -0.0166 & $-0.1537^{* * *}$ & -0.0192 \\
\hline & {$[0.0782]$} & [0.0029] & {$[0.0365]$} & [0.0033] \\
\hline \multirow[t]{2}{*}{ MS2 (Currently Married) } & $-2.4488 * * *$ & -0.4896 & $-0.7126^{* * *}$ & -0.1469 \\
\hline & {$[0.0689]$} & {$[0.0139]$} & {$[0.1188]$} & [0.0288] \\
\hline \multirow[t]{2}{*}{ MS3 (Formerly Married) } & $0.3767^{* * *}$ & 0.0300 & $1.9015^{* * *}$ & 0.572 \\
\hline & {$[0.0825]$} & {$[0.0061]$} & {$[0.1225]$} & [0.0373] \\
\hline \multirow[t]{2}{*}{ AGE2 (20-24) } & $0.2582^{* * *}$ & 0.0184 & $0.0732^{* *}$ & 0.0099 \\
\hline & {$[0.0766]$} & {$[0.0046]$} & [0.0367] & [0.0036] \\
\hline \multirow[t]{2}{*}{ AGE3 (25-29) } & $0.5144^{* * *}$ & 0.0423 & $-0.1239 * * *$ & -0.0157 \\
\hline & {$[0.0839]$} & {$[0.0067]$} & {$[0.0374]$} & [0.0032] \\
\hline \multirow[t]{2}{*}{ AGE4 (30-34) } & $0.5454^{* * *}$ & 0.0456 & $-0.3396^{* * *}$ & -0.0393 \\
\hline & {$[0.0997]$} & {$[0.0080]$} & [0.0391] & [0.0028] \\
\hline \multirow[t]{2}{*}{ AGE5 (35-39) } & $0.7151^{* * *}$ & 0.0644 & $-0.3987 * * *$ & -0.0444 \\
\hline & {$[0.1046]$} & {$[0.0094]$} & [0.0395] & [0.0027] \\
\hline \multirow[t]{2}{*}{ AGE6 (40-44) } & $1.1420^{* * *}$ & 0.1206 & $-0.1588 * * *$ & -0.0195 \\
\hline & {$[0.1001]$} & {$[0.0116]$} & {$[0.0398]$} & [0.0033] \\
\hline \multirow[t]{2}{*}{ AGE7 (45-49) } & $1.4382^{* * *}$ & 0.1719 & $0.1788^{* * *}$ & 0.0257 \\
\hline & {$[0.0988]$} & {$[0.0139]$} & {$[0.0401]$} & [0.0046] \\
\hline \multirow[t]{2}{*}{ AGE8 (50-54) } & $1.8156^{* * *}$ & 0.2677 & n.a. & n.a. \\
\hline & {$[0.1001]$} & {$[0.0183]$} & & \\
\hline \multirow[t]{2}{*}{ LOC (Urban) } & $-0.0739^{*}$ & -0.0045 & $-0.0538 * *$ & -0.0070 \\
\hline & [0.0418] & {$[0.0020]$} & [0.0208] & [0.0021] \\
\hline Religion Dummies & yes & & yes & \\
\hline State Dummies & yes & & yes & \\
\hline Observations & 49573 & & 93994 & \\
\hline LR-Chi & $8055.4^{* * *}$ & & $20001 * * *$ & \\
\hline McFadden's pseudo $R^{2}$ & 0.406 & & 0.299 & \\
\hline
\end{tabular}

Note: all variables weighted with recommended sample weights. Robust standard errors in brackets. ${ }^{*}$ significant at $10 \%$; ${ }^{* *}$ significant at $5 \%$; ${ }^{* *}$ significant at $1 \%$. $\mathrm{APE}=$ average partial effect. 
Table 6: Abstinence - virginity (only never married individuals)

\begin{tabular}{|c|c|c|c|c|}
\hline \multicolumn{5}{|l|}{ "Dependent Variable $=1$ if virgin } \\
\hline \multirow[t]{2}{*}{ Independent Variables } & \multicolumn{2}{|c|}{ Males } & \multicolumn{2}{|c|}{ Females } \\
\hline & Coeff. & APE & Coeff. & APE \\
\hline \multirow[t]{2}{*}{ EDUC2 (Primary Education) } & $-0.1133^{*}$ & -0.0236 & -0.0801 & -0.0016 \\
\hline & {$[0.0666]$} & {$[0.0092]$} & {$[0.1243]$} & [0.0017] \\
\hline \multirow[t]{2}{*}{ EDUC3 (Secondary Education) } & 0.0157 & 0.0031 & 0.1754 & 0.0034 \\
\hline & {$[0.0572]$} & {$[0.0074]$} & {$[0.1225]$} & {$[0.0015]$} \\
\hline \multirow[t]{2}{*}{ EDUC4 (Higher Education) } & $0.2244^{* * *}$ & 0.0413 & $0.3466^{* *}$ & 0.0050 \\
\hline & {$[0.0684]$} & {$[0.0078]$} & {$[0.1733]$} & {$[0.0014]$} \\
\hline \multirow[t]{2}{*}{ WEALTH2 (Poorer Quintile) } & -0.0125 & -0.0025 & 0.0720 & 0.0013 \\
\hline & {$[0.0565]$} & {$[0.0074]$} & {$[0.1211]$} & [0.0014] \\
\hline \multirow[t]{2}{*}{ WEALTH3 (Middle Quintile) } & $0.0975^{*}$ & 0.0189 & $0.2236^{*}$ & 0.0038 \\
\hline & {$[0.0554]$} & {$[0.0070]$} & {$[0.1269]$} & [0.0013] \\
\hline \multirow[t]{2}{*}{ WEALTH4 (Richer Quintile) } & $0.1799^{* * *}$ & 0.0343 & $0.4482^{* * *}$ & 0.0068 \\
\hline & {$[0.0573]$} & {$[0.0071]$} & {$[0.1541]$} & [0.0013] \\
\hline \multirow[t]{2}{*}{ WEALTH5 (Richest Quintile) } & $0.3136^{* * *}$ & 0.0584 & $0.6400 * * *$ & 0.0093 \\
\hline & [0.0637] & {$[0.0075]$} & [0.1628] & [0.0017] \\
\hline \multirow[t]{2}{*}{ AGE2 (20-24) } & $-0.5492 * * *$ & -0.1203 & $-0.5145^{* * *}$ & -0.0137 \\
\hline & [0.0339] & {$[0.0054]$} & {$[0.0850]$} & [0.0023] \\
\hline \multirow[t]{2}{*}{ AGE3 (25-29) } & $-0.7584^{* * *}$ & -0.1937 & $-0.5606^{* * *}$ & -0.0186 \\
\hline & [0.0433] & {$[0.0091]$} & {$[0.1539]$} & [0.0063] \\
\hline \multirow[t]{2}{*}{ AGE4 (30-34) } & $-0.8870 * * *$ & -0.2474 & -0.3241 & -0.0086 \\
\hline & {$[0.0675]$} & {$[0.0170]$} & {$[0.2250]$} & [0.0088] \\
\hline \multirow[t]{2}{*}{ AGE5 (35-39) } & $-0.8055^{* * *}$ & -0.2224 & $-0.6432 * *$ & -0.0240 \\
\hline & {$[0.1127]$} & {$[0.0281]$} & {$[0.3052]$} & [0.0149] \\
\hline \multirow[t]{2}{*}{ AGE6 (40-44) } & $-0.4072^{* *}$ & -0.0979 & -0.5576 & -0.0191 \\
\hline & {$[0.1576]$} & {$[0.0331]$} & {$[0.3599]$} & [0.0167] \\
\hline \multirow[t]{2}{*}{ AGE7 (45-49) } & $-0.8685^{* * *}$ & -0.2451 & $-0.8194^{*}$ & -0.0368 \\
\hline & [0.1673] & {$[0.0529]$} & {$[0.4189]$} & [0.0295] \\
\hline \multirow[t]{2}{*}{ AGE8 (50-54) } & $-0.8311^{* * *}$ & -0.2322 & n.a. & n.a. \\
\hline & {$[0.2052]$} & {$[0.0527]$} & & \\
\hline \multirow[t]{2}{*}{ LOC (Urban) } & 0.0403 & 0.0080 & 0.0403 & 0.0007 \\
\hline & {$[0.0344]$} & {$[0.0049]$} & {$[0.0922]$} & [0.0014] \\
\hline Religion Dummies & yes & & yes & \\
\hline State Dummies & yes & & yes & \\
\hline Observations & 28457 & & 28912 & \\
\hline LR-Chi & $1867.2^{* * *}$ & & $451.66^{* * *}$ & \\
\hline McFadden's pseudo $R^{2}$ & 0.083 & & 0.166 & \\
\hline
\end{tabular}

Note: all variables weighted with recommended sample weights. Robust standard errors in brackets. ${ }^{*}$ significant at $10 \% ;{ }^{* *}$ significant at $5 \%$; ${ }^{* *}$ significant at $1 \%$. $\mathrm{APE}=$ average partial effect. 
Table 7: Abstinence - age at first sex (excludes virgins)

\begin{tabular}{|c|c|c|}
\hline Dependent Variable $=$ age in ye & rs of first se & al intercour \\
\hline Independent Variables & Males & Females \\
\hline EDUC2 (Primary Education) & 0.1124 & $0.3568^{*}$ \\
\hline & {$[0.0747]$} & {$[0.1877]$} \\
\hline EDUC3 (Secondary Education) & $1.0789 * * *$ & $0.7414^{* * *}$ \\
\hline & {$[0.0684]$} & {$[0.1639]$} \\
\hline EDUC4 (Higher Education) & $3.1427 * * *$ & $3.1711^{* * *}$ \\
\hline & {$[0.1031]$} & {$[0.2146]$} \\
\hline WEALTH2 (Poorer Quintile) & -0.0159 & -0.2627 \\
\hline & {$[0.0813]$} & {$[0.2113]$} \\
\hline WEALTH3 (Middle Quintile) & $0.2489 * * *$ & -0.1246 \\
\hline & {$[0.0842]$} & {$[0.2103]$} \\
\hline WEALTH4 (Richer Quintile) & $0.6992^{* * *}$ & $0.4207^{*}$ \\
\hline & {$[0.0923]$} & {$[0.2344]$} \\
\hline WEALTH5 (Richest Quintile) & $1.6370^{* * *}$ & 0.0725 \\
\hline & {$[0.1062]$} & {$[0.2507]$} \\
\hline MS2 (Currently Married) & $0.9422^{* * *}$ & $-6.2010^{* * *}$ \\
\hline & {$[0.0956]$} & {$[2.1971]$} \\
\hline MS3 (Formerly Married) & $0.9555^{* * *}$ & $-6.5816^{* * *}$ \\
\hline & {$[0.2197]$} & {$[2.2109]$} \\
\hline AGE2 (20-24) & $2.3582^{* * *}$ & $1.8775^{* * *}$ \\
\hline & {$[0.1123]$} & {$[0.1554]$} \\
\hline AGE3 (25-29) & $3.7562^{* * *}$ & $3.4590 * * *$ \\
\hline & {$[0.1216]$} & {$[0.1861]$} \\
\hline AGE4 (30-34) & $4.5089 * * *$ & $3.5740 * * *$ \\
\hline & {$[0.1269]$} & {$[0.1924]$} \\
\hline AGE5 (35-39) & $4.7307^{* * *}$ & $3.7791 * * *$ \\
\hline & {$[0.1299]$} & {$[0.2056]$} \\
\hline AGE6 (40-44) & $4.9311^{* * *}$ & $3.5874 * * *$ \\
\hline & {$[0.1348]$} & {$[0.2132]$} \\
\hline AGE7 (45-49) & $5.1132 * * *$ & $3.6030 * * *$ \\
\hline & {$[0.1377]$} & {$[0.2260]$} \\
\hline AGE8 (50-54) & $5.2199 * * *$ & n.a. \\
\hline & {$[0.1492]$} & \\
\hline LOC (Urban) & $0.5820 * * *$ & $0.6916^{* * *}$ \\
\hline & {$[0.0601]$} & {$[0.1486]$} \\
\hline Religion Dummies & yes & yes \\
\hline State Dummies & yes & yes \\
\hline Observations & 49700 & 93993 \\
\hline $\mathrm{F}$ & $383.5^{* * *}$ & $76.61^{* * *}$ \\
\hline$R^{2}$ & 0.304 & 0.023 \\
\hline
\end{tabular}

Note: all variables weighted with recommended sample weights. Robust standard errors in brackets. * significant at $10 \%$; ${ }^{* *}$ significant at $5 \%$; ${ }^{* *}$ significant at $1 \%$. 
Table 8: HIV/AIDS Knowledge - ever heard of AIDS

\begin{tabular}{|c|c|c|c|c|}
\hline \multicolumn{5}{|c|}{ Dependent Variable $=1$ if ever heard of AIDS } \\
\hline \multirow[t]{2}{*}{ Independent Variables } & \multicolumn{2}{|c|}{ Males } & \multicolumn{2}{|c|}{ Females } \\
\hline & Coeff. & APE & Coeff. & APE \\
\hline \multirow[t]{2}{*}{ EDUC2 (Primary Education) } & $0.4870^{* * *}$ & 0.0754 & $0.5518^{* * *}$ & 0.1262 \\
\hline & {$[0.0259]$} & {$[0.0024]$} & {$[0.0164]$} & [0.0027] \\
\hline \multirow[t]{2}{*}{ EDUC3 (Secondary Education) } & $1.2249 * * *$ & 0.2346 & $1.2129 * * *$ & 0.3254 \\
\hline & {$[0.0262]$} & {$[0.0035]$} & {$[0.0166]$} & [0.0032] \\
\hline \multirow[t]{2}{*}{ EDUC4 (Higher Education) } & $2.3146^{* * *}$ & 0.1924 & $2.5161 * * *$ & 0.3929 \\
\hline & {$[0.0928]$} & {$[0.0017]$} & {$[0.0883]$} & [0.0030] \\
\hline \multirow[t]{2}{*}{ WEALTH2 (Poorer Quintile) } & $0.3642^{* * *}$ & 0.0575 & $0.3172 * * *$ & 0.0711 \\
\hline & {$[0.0274]$} & {$[0.0027]$} & {$[0.0191]$} & [0.0029] \\
\hline \multirow[t]{2}{*}{ WEALTH3 (Middle Quintile) } & $0.5936^{* * *}$ & 0.0926 & $0.5936^{* * *}$ & 0.1354 \\
\hline & {$[0.0296]$} & {$[0.0029]$} & {$[0.0196]$} & [0.0031] \\
\hline \multirow[t]{2}{*}{ WEALTH4 (Richer Quintile) } & $0.8154^{* * *}$ & 0.1218 & $0.9020 * * *$ & 0.2130 \\
\hline & {$[0.0357]$} & {$[0.0031]$} & {$[0.0217]$} & [0.0035] \\
\hline \multirow[t]{2}{*}{ WEALTH5 (Richest Quintile) } & $1.0751^{* * *}$ & 0.1435 & $1.2231 * * *$ & 0.2839 \\
\hline & {$[0.0460]$} & {$[0.0032]$} & {$[0.0266]$} & [0.0041] \\
\hline \multirow[t]{2}{*}{ MS2 (Currently Married) } & 0.0476 & 0.0079 & $-0.0818^{* * *}$ & -0.0190 \\
\hline & {$[0.0369]$} & [0.0043] & {$[0.0226]$} & [0.0039] \\
\hline \multirow[t]{2}{*}{ MS3 (Formerly Married) } & $-0.1339^{*}$ & -0.0232 & $-0.0870 * *$ & -0.0202 \\
\hline & {$[0.0720]$} & {$[0.0092]$} & {$[0.0350]$} & [0.0061] \\
\hline \multirow[t]{2}{*}{ AGE2 (20-24) } & $0.2792^{* * *}$ & 0.0441 & $0.1661 * * *$ & 0.0385 \\
\hline & {$[0.0394]$} & {$[0.0040]$} & {$[0.0235]$} & [0.0039] \\
\hline \multirow[t]{2}{*}{ AGE3 (25-29) } & $0.2437^{* * *}$ & 0.0387 & $0.1728 * * *$ & 0.0399 \\
\hline & {$[0.0464]$} & {$[0.0048]$} & {$[0.0256]$} & [0.0042] \\
\hline \multirow[t]{2}{*}{ AGE4 (30-34) } & $0.0992^{* *}$ & 0.0162 & $0.1357 * * *$ & 0.0313 \\
\hline & {$[0.0491]$} & {$[0.0054]$} & {$[0.0265]$} & [0.0044] \\
\hline \multirow[t]{2}{*}{ AGE5 (35-39) } & 0.0122 & 0.0020 & $0.1151^{* * *}$ & 0.0266 \\
\hline & {$[0.0496]$} & {$[0.0057]$} & {$[0.0269]$} & [0.0045] \\
\hline \multirow[t]{2}{*}{ AGE6 (40-44) } & $-0.1548^{* * *}$ & -0.0268 & 0.0441 & 0.0102 \\
\hline & {$[0.0506]$} & {$[0.0062]$} & {$[0.0282]$} & [0.0048] \\
\hline \multirow[t]{2}{*}{ AGE7 (45-49) } & $-0.2818^{* * *}$ & -0.0503 & $-0.0687 * *$ & -0.0160 \\
\hline & {$[0.0518]$} & {$[0.0067]$} & {$[0.0300]$} & [0.0052] \\
\hline \multirow[t]{2}{*}{ AGE8 (50-54) } & $-0.3791 * * *$ & -0.0695 & n.a. & n.a. \\
\hline & [0.0547] & {$[0.0075]$} & & \\
\hline \multirow[t]{2}{*}{ LOC (Urban) } & $0.3076^{* * *}$ & 0.0499 & $0.2712^{* * *}$ & 0.0645 \\
\hline & {$[0.0267]$} & {$[0.0030]$} & {$[0.0153]$} & [0.0029] \\
\hline Religion Dummies & yes & & yes & \\
\hline State Dummies & yes & & yes & \\
\hline Observations & 74313 & & 124382 & \\
\hline LR-Chi & $23452^{* * *}$ & & $63416^{* * *}$ & \\
\hline McFadden's pseudo $R^{2}$ & 0.345 & & 0.381 & \\
\hline
\end{tabular}

Note: all variables weighted with recommended sample weights. Robust standard errors in brackets. ${ }^{*}$ significant at $10 \%$; ${ }^{* *}$ significant at $5 \%$; ${ }^{* *}$ significant at $1 \%$. $\mathrm{APE}=$ average partial effect. 
Table 9: HIV/AIDS Knowledge - can healthy person have AIDS

\begin{tabular}{|c|c|c|c|c|}
\hline \multicolumn{5}{|c|}{ Dependent Variable $=1$ knows healthy looking person can have AIDS } \\
\hline \multirow[t]{2}{*}{ Independent Variables } & \multicolumn{2}{|c|}{ Males } & \multicolumn{2}{|c|}{ Females } \\
\hline & Coeff. & APE & Coeff. & APE \\
\hline \multirow[t]{2}{*}{ EDUC2 (Primary Education) } & $0.1046^{* * *}$ & 0.0307 & $0.0577^{* * *}$ & 0.0201 \\
\hline & {$[0.0290]$} & {$[0.0057]$} & {$[0.0212]$} & {$[0.0052]$} \\
\hline \multirow{2}{*}{ EDUC3 (Secondary Education) } & $0.3970 * * *$ & 0.1227 & $0.3329 * * *$ & 0.1181 \\
\hline & {$[0.0260]$} & {$[0.0056]$} & {$[0.0186]$} & {$[0.0046]$} \\
\hline \multirow[t]{2}{*}{ EDUC4 (Higher Education) } & $0.7903^{* * *}$ & 0.1966 & $0.8252^{* * *}$ & 0.2550 \\
\hline & {$[0.0358]$} & [0.0048] & {$[0.0277]$} & {$[0.0050]$} \\
\hline \multirow[t]{2}{*}{ WEALTH2 (Poorer Quintile) } & $0.0556^{*}$ & 0.0165 & 0.0361 & 0.0126 \\
\hline & {$[0.0316]$} & [0.0060] & {$[0.0301]$} & {$[0.0071]$} \\
\hline \multirow[t]{2}{*}{ WEALTH3 (Middle Quintile) } & $0.1419 * * *$ & 0.0416 & $0.1283^{* * *}$ & 0.0444 \\
\hline & {$[0.0305]$} & {$[0.0058]$} & {$[0.0287]$} & {$[0.0066]$} \\
\hline \multirow[t]{2}{*}{ WEALTH4 (Richer Quintile) } & $0.2883^{* * *}$ & 0.0834 & $0.2343^{* * *}$ & 0.0808 \\
\hline & {$[0.0317]$} & [0.0059] & {$[0.0291]$} & {$[0.0067]$} \\
\hline \multirow[t]{2}{*}{ WEALTH5 (Richest Quintile) } & $0.4696^{* * *}$ & 0.1337 & $0.3986^{* * *}$ & 0.1399 \\
\hline & {$[0.0351]$} & {$[0.0064]$} & {$[0.0311]$} & {$[0.0074]$} \\
\hline \multirow[t]{2}{*}{ MS2 (Currently Married) } & 0.0341 & 0.0103 & -0.0283 & -0.0099 \\
\hline & [0.0271] & {$[0.0056]$} & {$[0.0205]$} & {$[0.0052]$} \\
\hline \multirow[t]{2}{*}{ MS3 (Formerly Married) } & -0.0659 & -0.0202 & -0.0013 & -0.0004 \\
\hline & {$[0.0767]$} & {$[0.0162]$} & {$[0.0372]$} & {$[0.0094]$} \\
\hline \multirow[t]{2}{*}{ AGE2 (20-24) } & $0.1302^{* * *}$ & 0.0382 & 0.0119 & 0.0042 \\
\hline & {$[0.0270]$} & [0.0054] & {$[0.0220]$} & {$[0.0056]$} \\
\hline \multirow[t]{2}{*}{ AGE3 (25-29) } & $0.2013^{* * *}$ & 0.0582 & -0.0172 & -0.0060 \\
\hline & {$[0.0325]$} & [0.0063] & {$[0.0255]$} & {$[0.0065]$} \\
\hline \multirow[t]{2}{*}{ AGE4 (30-34) } & $0.1727 * * *$ & 0.0501 & -0.0287 & -0.0101 \\
\hline & {$[0.0370]$} & [0.0072] & {$[0.0273]$} & {$[0.0069]$} \\
\hline \multirow[t]{2}{*}{ AGE5 (35-39) } & $0.1799 * * *$ & 0.0520 & -0.0338 & -0.0119 \\
\hline & {$[0.0388]$} & {$[0.0074]$} & {$[0.0283]$} & {$[0.0072]$} \\
\hline \multirow[t]{2}{*}{ AGE6 (40-44) } & $0.1819 * * *$ & 0.0524 & -0.0463 & -0.0164 \\
\hline & {$[0.0406]$} & [0.0077] & {$[0.0298]$} & {$[0.0076]$} \\
\hline \multirow[t]{2}{*}{ AGE7 (45-49) } & $0.1047^{* *}$ & 0.0307 & $-0.0652^{* *}$ & -0.0231 \\
\hline & {$[0.0422]$} & [0.0083] & {$[0.0325]$} & {$[0.0083]$} \\
\hline \multirow[t]{2}{*}{ AGE8 (50-54) } & $0.1035^{* *}$ & 0.0303 & n.a. & n.a. \\
\hline & {$[0.0452]$} & [0.0091] & & \\
\hline \multirow[t]{2}{*}{ LOC (Urban) } & $0.0565 * * *$ & 0.0170 & $0.0393^{* * *}$ & 0.0138 \\
\hline & {$[0.0182]$} & [0.0040] & {$[0.0144]$} & {$[0.0037]$} \\
\hline Religion Dummies & yes & & yes & \\
\hline State Dummies & yes & & yes & \\
\hline Observations & 65952 & & 88382 & \\
\hline LR-Chi & $6037.1^{* * *}$ & & $8443.2^{* * *}$ & \\
\hline McFadden's pseudo $R^{2}$ & 0.079 & & 0.072 & \\
\hline
\end{tabular}

Note: all variables weighted with recommended sample weights. Robust standard errors in brackets. ${ }^{*}$ significant at $10 \%$; ${ }^{* *}$ significant at $5 \%$; ${ }^{* *}$ significant at $1 \%$. $\mathrm{APE}=$ average partial effect. 
Table 10: Stigma

\begin{tabular}{|c|c|c|c|c|}
\hline \multicolumn{5}{|c|}{ Dependent Variable $=1$ if would not buy vegetables from person with AIDS } \\
\hline \multirow{2}{*}{ Independent Variables } & \multicolumn{2}{|c|}{ Males } & \multicolumn{2}{|c|}{ Females } \\
\hline & Coeff. & APE & Coeff. & APE \\
\hline \multirow[t]{2}{*}{ EDUC2 (Primary Education) } & $-0.0908^{* * *}$ & -0.0294 & $-0.1103^{* * *}$ & -0.0363 \\
\hline & {$[0.0295]$} & {$[0.0065]$} & {$[0.0220]$} & {$[0.0050]$} \\
\hline \multirow[t]{2}{*}{ EDUC3 (Secondary Education) } & $-0.4255^{* * *}$ & -0.1428 & $-0.4261 * * *$ & -0.1454 \\
\hline & {$[0.0262]$} & {$[0.0061]$} & {$[0.0194]$} & [0.0047] \\
\hline \multirow[t]{2}{*}{ EDUC4 (Higher Education) } & $-0.9537 * * *$ & -0.2718 & $-0.9467 * * *$ & -0.2714 \\
\hline & {$[0.0353]$} & {$[0.0054]$} & {$[0.0294]$} & [0.0047] \\
\hline \multirow[t]{2}{*}{ WEALTH2 (Poorer Quintile) } & $-0.1362^{* * *}$ & -0.0438 & -0.0203 & -0.0068 \\
\hline & {$[0.0319]$} & {$[0.0065]$} & {$[0.0314]$} & [0.0071] \\
\hline \multirow[t]{2}{*}{ WEALTH3 (Middle Quintile) } & $-0.2603^{* * *}$ & -0.0825 & $-0.1311^{* * *}$ & -0.0431 \\
\hline & [0.0307] & {$[0.0062]$} & [0.0299] & {$[0.0066]$} \\
\hline \multirow[t]{2}{*}{ WEALTH4 (Richer Quintile) } & $-0.4725^{* * *}$ & -0.1489 & $-0.3130 * * *$ & -0.1021 \\
\hline & {$[0.0317]$} & {$[0.0063]$} & {$[0.0305]$} & {$[0.0065]$} \\
\hline \multirow[t]{2}{*}{ WEALTH5 (Richest Quintile) } & $-0.6127 * * *$ & -0.1956 & $-0.4516^{* * *}$ & -0.1506 \\
\hline & {$[0.0349]$} & {$[0.0071]$} & [0.0327] & [0.0073] \\
\hline \multirow[t]{2}{*}{ MS2 (Currently Married) } & $0.1372^{* * *}$ & 0.0452 & $0.1322 * * *$ & 0.0441 \\
\hline & {$[0.0259]$} & {$[0.0060]$} & {$[0.0219]$} & [0.0052] \\
\hline \multirow[t]{2}{*}{ MS3 (Formerly Married) } & 0.0855 & 0.0284 & $0.0949^{* *}$ & 0.0322 \\
\hline & {$[0.0758]$} & {$[0.0174]$} & {$[0.0384]$} & [0.0095] \\
\hline \multirow[t]{2}{*}{ AGE2 (20-24) } & $-0.0681^{* *}$ & -0.0223 & $-0.0458^{*}$ & -0.0153 \\
\hline & {$[0.0273]$} & {$[0.0062]$} & {$[0.0235]$} & [0.0056] \\
\hline \multirow[t]{2}{*}{ AGE3 (25-29) } & $-0.0912^{* * *}$ & -0.0297 & 0.0093 & 0.0031 \\
\hline & {$[0.0318]$} & {$[0.0073]$} & {$[0.0270]$} & [0.0065] \\
\hline \multirow[t]{2}{*}{ AGE4 (30-34) } & -0.0044 & -0.0014 & $0.0637^{* *}$ & 0.0215 \\
\hline & {$[0.0357]$} & {$[0.0084]$} & {$[0.0287]$} & [0.0069] \\
\hline \multirow[t]{2}{*}{ AGE5 (35-39) } & 0.0340 & 0.0112 & $0.1123^{* * *}$ & 0.0381 \\
\hline & {$[0.0376]$} & {$[0.0088]$} & {$[0.0295]$} & [0.0073] \\
\hline \multirow[t]{2}{*}{ AGE6 (40-44) } & $0.1539 * * *$ & 0.0516 & $0.1731 * * *$ & 0.0592 \\
\hline & {$[0.0395]$} & {$[0.0094]$} & {$[0.0312]$} & [0.0078] \\
\hline \multirow[t]{2}{*}{ AGE7 (45-49) } & $0.1587^{* * *}$ & 0.0532 & $0.1838^{* * *}$ & 0.0629 \\
\hline & {$[0.0402]$} & {$[0.0099]$} & {$[0.0340]$} & [0.0085] \\
\hline \multirow[t]{2}{*}{ AGE8 (50-54) } & $0.1836^{* * *}$ & 0.0618 & n.a. & n.a. \\
\hline & {$[0.0438]$} & {$[0.0108]$} & & \\
\hline \multirow[t]{2}{*}{ LOC (Urban) } & $-0.1522 * * *$ & -0.0504 & $-0.0916^{* * *}$ & -0.0308 \\
\hline & {$[0.0177]$} & [0.0043] & {$[0.0150]$} & [0.0037] \\
\hline Religion Dummies & yes & & yes & \\
\hline State Dummies & yes & & yes & \\
\hline Observations & 63706 & & 83836 & \\
\hline LR-Chi & $9545.5^{* * *}$ & & $11611^{* * *}$ & \\
\hline McFadden's pseudo $R^{2}$ & 0.115 & & 0.105 & \\
\hline
\end{tabular}

Note: all variables weighted with recommended sample weights. Robust standard errors in brackets. ${ }^{*}$ significant at $10 \%$; ${ }^{*}$ significant at $5 \%$; $* *$ significant at $1 \%$. $\mathrm{APE}=$ average partial effect. 
Table 11: Detailed Description of Variables

\begin{tabular}{|c|c|c|}
\hline Code & Variable & Definition \\
\hline \multicolumn{3}{|c|}{ Dependent Variables } \\
\hline $\mathrm{CU}$ & Condom use & $\begin{array}{l}=1 \text { if individual used condom in last sexual } \\
\text { intercourse } ;=0 \text { otherwise }\end{array}$ \\
\hline EMS & Extra marital sex & $\begin{array}{l}=1 \text { if number of sexual relations with other } \\
\text { than wife or husband in past year }>0 ;=0 \\
\text { otherwise }\end{array}$ \\
\hline $\mathrm{ABT}$ & Time in months since last sex & $\begin{array}{l}=1 \text { last sexual intercourse }>12 \text { months } ;=0 \\
\text { otherwise }\end{array}$ \\
\hline VIR & Virginity status & $=1$ if never had sex $;=0$ otherwise \\
\hline FS & First sex & Age in years of sexual debut \\
\hline EHA & General knowledge about AIDS & $=1$ if has ever heard of AIDS; $=0$ otherwise \\
\hline HLP & Specific knowledge about AIDS & $\begin{array}{l}=1 \text { if knowns a healthy looking person can } \\
\text { have AIDS; }=0 \text { otherwise }\end{array}$ \\
\hline VEG & HIV/AIDS stigma & $\begin{array}{l}=1 \text { if would not buy vegetable from an AIDS } \\
\text { infected person; }=0 \text { otherwise }\end{array}$ \\
\hline \multicolumn{3}{|c|}{ Independent Variables } \\
\hline AGE & Age in years & $\begin{array}{l}\text { Five year age groups: } 15-19,20-24,25-29,30- \\
34,35-39,40-44,45-49,50-54\end{array}$ \\
\hline EDUC & Years of education & $\begin{array}{l}\text { Four categories: less than } 1 \text { year, between } 1 \\
\text { and } 5 \text { years, between } 6 \text { and } 12 \text { years, and more } \\
\text { than } 12 \text { years }\end{array}$ \\
\hline WEALTH & Wealth index (quintiles) & $\begin{array}{l}\text { Weighted average of individual's asset hold- } \\
\text { ings }\end{array}$ \\
\hline MS & Marital status & $\begin{array}{l}\text { Three categories: never married, currently } \\
\text { married, and formerly married }\end{array}$ \\
\hline $\mathrm{LOC}$ & Location of residence & Either urban or rural \\
\hline REL & Individual's religion & $\begin{array}{l}\text { Religions recorded: Hindu, Muslim, Chris- } \\
\text { tian, Sikh, Buddhist/neo-Buddhist, Jain, Jew- } \\
\text { ish, Parsi/Zoroastrian, Donyi Polo, no reli- } \\
\text { gion, and other. }\end{array}$ \\
\hline STATE & State of residence & $\begin{array}{l}\text { All states and territoriesrecorded: Jammu } \\
\text { and Kashmir, Himachal Pradesh, Punjab, } \\
\text { Uttaranchal, Haryana, Delhi, Rajasthan, } \\
\text { Uttar Pradesh, Bihar, Sikkim, Arunachal } \\
\text { Pradesh, Nagaland, Manipur, Mizoram, } \\
\text { Tripura, Meghalaya, Assam, West Ben- } \\
\text { gal, Jharkhand, Orissa, Chhattisgarh, Mad- } \\
\text { hya Pradesh, Gujarat, Maharashtra, Andhra } \\
\text { Pradesh, Karnataka, Goa, Kerala, and Tamil } \\
\text { Nadu. }\end{array}$ \\
\hline
\end{tabular}

